Filip Čuček*

\title{
K problematiki štajersko-hrvaške dravske meje konec 18. stoletja
}

\section{IZVLE $\check{C} E K$}

Na podlagi arhivskega gradiva se avtor posveča štajersko-hrvaški mejni reki Dravi (med Ormožem in Središčem) konec 18. stoletja, ko so se (zaradi sprememb rečne struge) pristojni organi pod Marijo Terezijo in Jožefom II. pričeli ukvarjati z nastalimi obmejnimi spori. Potem ko je Drava v 18. stoletju močno poplavljala, so se oškodovani obmejni prebivalci (na štajerski strani) vse bolj pritoževali in skušali rešiti nastali položaj. Avtorja predvsem zanima, kako je spreminjanje rečne struge vplivalo na življenje prebivalcev ob reki in kako so na prelomu stoletja (preden je bila meja $v$ začetku 19. stoletja usklajena in izrisana) reševali medsebojne lokalne zaplete.

Ključne besede: Avstrija, Ogrska, štajersko-hrvaška meja, 18. stoletje, Drava, Ormož, Središče

\section{ABSTRACT \\ ON THE ISSUE OF THE STYRIAN-CROATIAN BORDER ON THE RIVER DRAVA AT THE END OF THE $18^{\text {TH }}$ CENTURY}

On the basis of the archival materials the author focuses on the Styrian-Croatian border river Drava (between Ormož and Središce) at the end of the $18^{\text {th }}$ century, when (due to the river bed changes) the competent authorities under Maria Theresa and Joseph II started to focus on the consequent border disputes. After the massive floods of the river Drava in the $18^{\text {th }}$ century, the border residents who suffered damages (on the Styrian side) complained more and more frequently, trying to solve the situation at hand. The author is specifically interested in how the river bed changes influenced the life of the residents of the areas by the river and how these people solved the mutual local disputes at the turn of the century (before the border was agreed upon and drawn at the beginning of the $19^{\text {th }}$ century).

Keywords: Austria, Hungary, Styrian-Croatian border, $18^{\text {th }}$ century, Drava, Ormož, Središce

Območje »slovensko-hrvaške« meje je bilo v preteklosti prizorišče številnih sporov, ki so izhajali iz administrativnih meddeželnih razmerij (v obdobju Avstro-Ogr-

* dr., znanstveni sodelavec, Inštitut za novejšo zgodovino, Kongresni trg 1, SI - 1000 Ljubljana, filip.cucek@inz.si 
ske tudi iz (sko raj) meddržavnih razmerij), v času oblikovanja nacionalnih ideologij iz povsem nacionalnih vzgibov, ${ }^{1}$ do sporov pa je prihajalo tudi zaradi lokalnih zemljiško-gosposkih oziroma kmečko-posestnih razmerij na avstrijskih deželnih mejah. $\mathrm{Na}$ delu štajersko-hrvaške meje, ki je predmet te razprave, je pomembno vlogo odigrala deželna mejna reka Drava. Zemljiški posestniki, ki so imeli svojo posest ob reki (deželni meji), so se bili prisiljeni soočiti z dejstvom, da jim lahko deroča voda kadarkoli odnese rodovitno zemljo oziroma prestavi njihovo posest. Ker je Drava (na delu svojih vodotokov) zaradi preobilice vode pogosto menjavala svoj tok, ustvarjala številne otoke in na eni strani "povečevala« zdaj štajersko, drugič pa hrvaško zemljiško posest (ter obenem vplivala še na potek deželne meje), je vse do konca 20. let 19. stoletja, ko je bila štajersko-hrvaška meja usklajena, prihajalo do številnih trenj in napetosti. ${ }^{2}$

Čeprav je habsburška monarhija v drugi polovici 18. stoletja začela načrtno razvijati plovbo po sladkih vodah, ${ }^{3}$ se mejnim rečnim sporom na lokalni ravni v tem "projektu« seveda niso posebej posvečali. $S$ težavami na reki Dravi (na mejnem območju med mariborskim okrožjem in varaždinskim komitatom) sta se začela Marija Terezija in Jožef II. "spopadati« šele sredi sedemdesetih let. Proti koncu 18. stoletja so pristojni organi tako začeli analizirati obstoječe spore oziroma probleme, ki jih je narasla voda prinašala obmejnim prebivalcem med Ormožem in Središčem. Deroča reka je (ob najhujših vodotokih) marsikje spremenila strugo in presekala obstoječo (npr. štajersko) posest, ta pa je potem prešla na novega (hrvaškega) lastnika (oziroma si jo je ta prisvojil). V skladu s tem bi se moral spremeniti davek na posest, kar pa se ni zgodilo, saj so deželne deske še zmeraj beležile stare razmere in dajatve (štajerski kmet je npr. še zmeraj plačeval davek na posest, ki je po novem ležala na hrvaški stra-

1 O slovensko-hrvaških političnih odnosih v 19. stoletju širše gl. Darko Darovec et al., ur., Slovensko-hrvaško sosedstvo. Hrvatsko-slovensko susjedstvo. (Koper: Univerza na Primorskem, ZRS, Univerzitetna založba Annales in Zgodovinsko društvo za južno Primorsko, 2011). Andrej Rahten, Zavezništva in delitve. Razvoj slovensko-hrvaških političnih odnosov v habsburški monarhiji 1848-1918 (Ljubljana: Nova revija, 2005). Nataša Podgoršek, Slovensko-hrvaška vzajemnost. Zgodovina slovensko-hrvaških političnih odnosov v drugi polovici 19. stoletja: 1848-1903 (Maribor: Zgodovinsko društvo dr. Franca Kovačiča, 2009). Petar Korunić, Jugoslavenska ideologija u Hrvatskoj i slovenskoj politici. Hrvatsko-slovenski politički odnosi 1848-1870 (Zagreb: Globus: Centar za povijesne znanosti sveučilišta u Zagrebu, Odjel za hrvatsku povijest, 1986). Marko Zajc, Kje se slovensko neha in hrvaško začne. Slovensko-hrvaška meja v 19. in na začetku 20. stoletja (Ljubljana: Modrijan, 2006).

2 Prim. npr. Marko Zajc, "Sotla, majhna voda," Zgodovina za vse 19, št. 1-2 (2012): 101-13. Waltraud Heindl in Edith Sauer, »Grenzen und Grenzüberschreitung. Die Bedeutung der Grenze für die staatliche und soziale Entwicklung des Habsburgerreiches von der Mitte des 18. bis zur Mitte des 19. Jahrhunderts, "v: Ästhetik und Ideologie (Wien: Bundesministerium für Wissenschaft und Verkehr, 1997), 277-90.

3 Prim. Stanislav Južnič, »Gabrijel Gruber in navigacijski inženir Jurij Vega - 2. del, «Arhivi 29, št. 1 (2006): 36-63. Othmar Pickl, "Mur und Drau als Verkehrswege nach dem Südosten, « v: Razvoj prometnih zvez v panonskem prostoru do 1918. leta, ur. Vanek Šiftar et al. (Maribor: Univerza v Mariboru, 1977), 225-35. 


\section{Tok reke Drave na štajersko-hrvaški meji konec 18. stoletja}

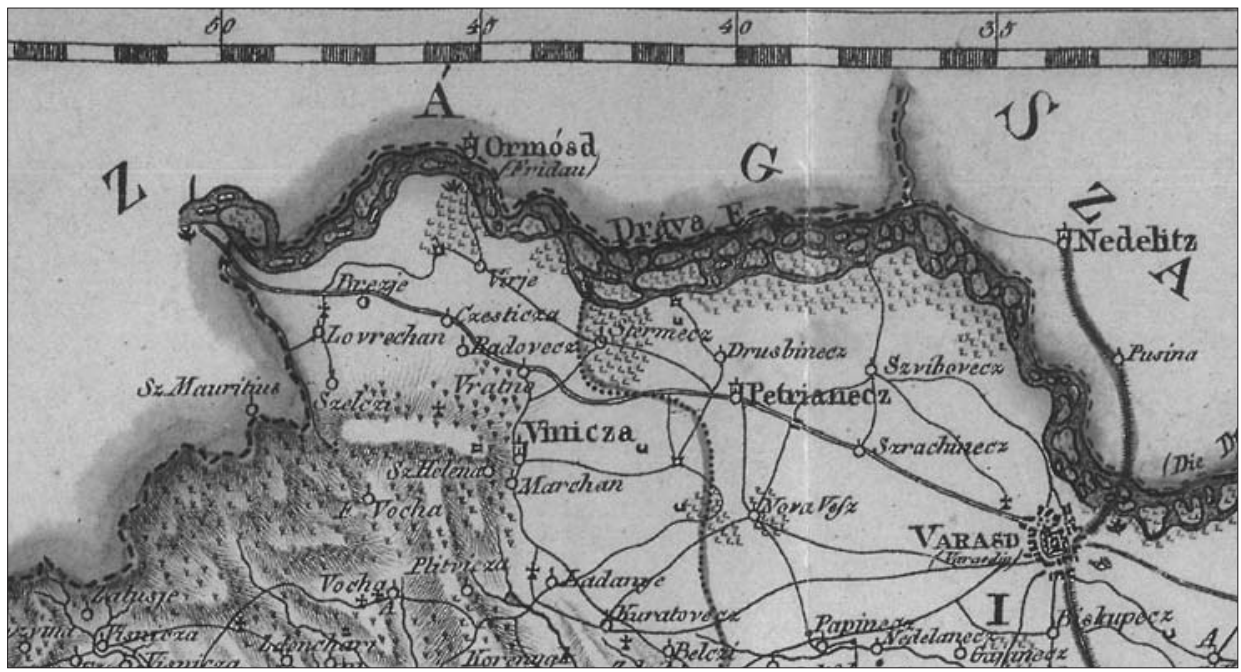

Valentić, Mirko et al. (ur.). Hrvatska na tajnim zemljovidima 18. i 19. stoljeća. Varaždinska županija. Oris terena. Zagreb, 2005

ni). Vse to je sprožalo nezadovoljstvo med dotičnim prebivalstvom, na drugi strani pa puščalo deželno mejo pravno neusklajeno.

Spreminjanje dravske struge je bilo v preteklosti (še posebej sredi 18. stol.) $)^{4}$ pereč problem za prebivalce ob reki. Pritožbe obmejnih podložnikov je posebna mejna komisija prvič obravnavala ob predvideni davčni reformi leta 1754,5 toda revizija je bila začeta zgolj z Ogrsko, ne pa s Hrvaško (ta se je strinjala, da se zadeva ureja med Štajersko in Ogrsko). Zadeva je tako ostala nedorečena. Mešana komisija je sicer zaslišala številne priče, toda umanjkale so topografske karte. Pritožbe je leta 1773 ponovno popisal pravni zastopnik ormoškega gospostva grof Brandis (deroča voda naj bi v Središču prestavila vrtove, njive in travnike, skupaj slabih 100 hektarjev $)^{6}$ - obstajala naj bi tudi dokumentacija iz leta $1765^{7}$ - toda to ni rešilo težav (upraviteljica ormoškega gospostva Polixena Welsersheimb naj prav tako ne bi podpisala dokumentov za odpis dolgov). ${ }^{8}$ Tako so se dunajske oblasti šele sredi sedemdesetih let začele resneje spopadati s tem problemom. Konec januarja 1775 so stanovi navajali, da se nekdanje

4 Fran Kovačič, Trg Središče. Krajepis in zgodovina (Maribor: Zgodovinsko društvo za Sl. Št., 1910), 485.

5 Prim. Vlado Valenčič, »Prebivalstvo Ljubljane pred dvesto leti,« Kronika 2, št. 3 (1954): 191. Jože Curk, "Oris Ormoža in Središča v fasijskem popisu iz leta 1754, «v: Ormož skozi stoletja III, ur. Peter P. Klasinc (Ormož: Skupščina občine, 1988), 73.

6 AT-OeStA, AVA Inneres HK Allgemein A 27 Landesgrenzen, Steiermark-Kroatien, 1550-1848, II. A.3. I. Stmk - Kroatien, 38 ex Februar 1779.

7 AT-OeStA, AVA Inneres HK Allgemein A 27 Landesgrenzen, Steiermark-Kroatien, 1550-1848, II. A.3. I. Öe. - Kroatien, 34 ex April 1788.

8 Prim. AT-OeStA, AVA Inneres HK Allgemein A 27 Landesgrenzen, Steiermark-Kroatien, 15501848, II. A.3. I. Öe. - Kroatien, 028 ex Jänner 1786. 
štajersko ozemlje vrne matični deželi, kar je prizadetim gotovo vlivalo določen optimizem. Februarja 1775 je bil izdan dekret, ki naj bi končno uravnal vprašanje davčne obveznosti na območjih, ki jih je ustvarila spremenjena dravska struga, ${ }^{9}$ prav tako pa je opredeljeval povračilo zaradi "vodne« škode (češ da naj se nadomestila v prihodnje povišajo) in se resno "zanimal« za nastalo stanje (kdaj so posestva postala hrvaška, kako je z vprašanjem restitucije in ureditvijo davka itd.). Dunaj je septembra 1775 vse to sprejel in potrdil, hkrati pa zapovedal, da se morajo postopki peljati naprej z natančno izdelano topografsko karto (ne da bi kršili pravice ene in druge strani), ki bo opredelila, kdo je upravičen do odškodnine in kdo ne (gospostvo Ormož je zadevo seveda hotelo čimprej zaključiti, zato je pridobilo pristojnega sodnika). Kljub vsemu je bil oktobra 1775 izdan cesarski rekurz, ki je podložnikom nekoliko popravil pravni položaj, toda zataknilo se je pri izvajanju določil v praksi (težko je bilo ugotoviti prvotno stanje na vseh odsekih reke, pridobiti relevantne priče in sprejeti končno odločitev). Komisija je sicer pregledala teren, tudi okrožni glavar je bil seznanjen s spornimi razmerami, temu pa je z vsemi sredstvi nasprotovala hrvaška stran, kar je seveda upočasnilo zastavljeni projekt. Kljub vsemu je bila detektirana stara struga, kar bi moralo pravico do ozemlja vrniti ormoškim podložnikom, težko pa je bilo pridobiti relevantne priče, ki bi to stanje potrjevale (to je proces ponovno upočasnilo). Razen tega do določitve ustreznega davka na spornih področjih še sploh ni prišlo. Glede na vse to je poročevalec predlagal določitev nove mešane komisije, ki bi ponovno pretresla zadevo in povsem na novo definirala obmejno posest, obtožbe, ki so se »vlekle« že več desetletij, pa bi bilo treba opustiti in reorganizirati obmejno življenje na pravni podlagi. ${ }^{10}$

Septembra 1777 je notranjeavstrijski gubernij prejel dopis dvorne pisarne, v katerem so slednjo zanimali stanje ob reki Dravi (med Ormožem in Središčem), ${ }^{11}$ poplavljenost obrečnih gozdov, pašnikov, travnikov, polj in livad ter $s$ tem povezanih sprememb rečne struge. Zaradi neurejenega stanja na meji je bilo namreč treba ponovno ugotoviti davčna bremena, ki so šla prizadetim kmetom, prav tako pa še odškodnino za izgubljeno posest. ${ }^{12}$ Gubernij je novembra poslal odgovor, v katerem je navajal, da je spreminjanje dravske struge povzročil silen vdor vode, to pa je obenem občutno podaljšalo potovanje na območju okrog Ormoža (in sicer za tri ure »v dolžino« in dve uri "v širino«). Glede na takšno stanje je gubernij predlagal gradnjo novih cest in obojestransko izdelavo topografske karte, ki bi ponovno vzpostavila red na davčnem področju (pravno osnovo je sicer podajal rekurz iz oktobra 1775). Poročevalec je menil, da bi bilo treba na problematičnih odsekih določiti novo davčno breme in

9 AT-OeStA, AVA Inneres HK Allgemein A 27 Landesgrenzen, Steiermark-Kroatien, 1550-1848, II. A.3. I. Öe. - Kroatien, 013 ex September 1777.

10 AT-OeStA, AVA Inneres HK Allgemein A 27 Landesgrenzen, Steiermark-Kroatien, 15501848, II. A.3. I. Stmk - Kroatien, 38 ex Februar 1779.

11 Prim. Vinko Rajšp et al., Slovenija na vojaškem zemljevidu 1763-1787. Zv. 6 (Ljubljana: ZRC SAZU in ARS, 2000), 217-26.

12 AT-OeStA, AVA Inneres HK Allgemein A 27 Landesgrenzen, Steiermark-Kroatien, 15501848, II. A.3. I. Öe. - Kroatien, 013 ex September 1777. 
dokončno ugotoviti vzrok škode (po njegovem je to bila voda, nikakor pa ne hrvaški podložniki, na kar so namigovali nekateri posamezniki). ${ }^{13}$

$\mathrm{Na}$ štajerski strani je sporno ozemlje pregledala posebna komisija, ki je ocenila, da je treba preostalo posest zavarovati in začeti z vodogradnjo (komisija je imela lažje delo tam, kjer so bile navzoče tudi priče, saj so lahko potem zadevo hitreje zaključili). $\mathrm{Na}$ odsekih, ki jih komisiji ni uspelo temeljito pregledati, je bila potrebna še dodatna analiza terena. Območje je morala tako obiskati nova komisija, ki bi podala ekspertizo o spornem ozemlju (ali so mejo spremenili poplavni nanosi ali pa deroča reka). Za komisijo so bili predvideni strokovnjaki, ki so poznali teren in so znali analizirati pretok vode, ob njih pa naj bi se ogleda udeležili še komisijski aktuar, upravitelj in pisar ormoškega gospostva, mestni sodnik, pravni zastopnik mesta Ormož in razne priče (brodarji). Razen tega bi bilo treba pregledati še nasprotno stran pa tudi ceste (proti Zavrču in Varaždinu), ${ }^{14}$ ki jih je voda zalila oziroma prestavila drugam. ${ }^{15}$

Ne glede na smelo zastavljene načrte pa se "nasprotna«stran, ki je imela od prestavljene struge dejansko še največ koristi, z njimi ni strinjala (še sploh gospod (plemeniti) Warkitsch, lastnik gospoščine ob stari dravski strugi). Na prihod mariborskega okrožnega glavarja se je hrvaška stran dobro pripravila, saj je njegov voz obstopilo pet Warkitschevih ljudi, »družbo" pa jim je delal še oborožen gozdar. Glavarju se je komaj uspelo obraniti (ohranil je mirno kri), tako da do kakšnih hujših ekscesov ni prišlo. Na dogodek pa sta obe strani gledali s svojimi očmi. Warkitsch je okrožnega glavarja obtožil, češ da mu je šlo zgolj za denar in da je hotel zaslužiti z "nečednimi« posli, ki bi jih dobil z oddajo del na reki. Štajerska stran je te trditve seveda zavračala, saj naj bi okrožnega glavarja že zaslišala komisija, ki pri njem nikakor ni odkrila ničesar sumljivega. Po njenem mnenju naj bi se z nečednimi posli pečal prav Warkitsch, ki je mešetaril med hrvaškimi in štajerskimi obmejnimi podložniki (ti so njegovo nesramno početje tudi odkrili). Po mnenju poročevalca bi moral biti Warkitsch kaznovan, saj je vendarle treba ohraniti ugled in zagotoviti varnost državnih uradnikov, ki zgolj opravljajo svoje delo. ${ }^{16}$

Dvorna pisarna je dobljeno poročilo skrbno prebrala in arhivirala, konec leta 1777 pa še enkrat poudarila težave na Dravi (gospostvo Ormož) in problematizirala prestavljeno ozemlje oziroma oškodovano lastnino, prav tako pa tudi lastnike spornih parcel, ki še niso bili pravno obravnavani (se pravi, da o morebitni odškodnini še ni bilo ne duha ne sluha). Na drugi strani je dvorna pisarna navajala (po poročilu varaždinskega komitata in mariborskega okrožnega glavarja), da je skušala štajerska stran za preprečitev novih poplav zajeziti reko, hrvaška stran pa naj bi to z vsemi sredstvi ovirala. Zato je predlagala ustanovitev obojestranske komisije, ki bi (z vsemi

13 AT-OeStA, AVA Inneres HK Allgemein A 27 Landesgrenzen, Steiermark-Kroatien, 15501848, II. A.3. I. Stmk - Kroatien, 38 ex Februar 1779.

14 Hrvaško stran reke prim. v Mirko Valentić et al., ur., Hrvatska na tajnim zemljovidima 18. i 19. stoljeća. Varaždinska županija (Zagreb: Hrvatski institut za povijest, 2005), 123-35.

15 AT-OeStA, AVA Inneres HK Allgemein A 27 Landesgrenzen, Steiermark-Kroatien, 15501848, II. A.3. I. Stmk - Kroatien, 38 ex Februar 1779.

16 Ibid. 


\section{Ormožz okolico na štajerski karti}

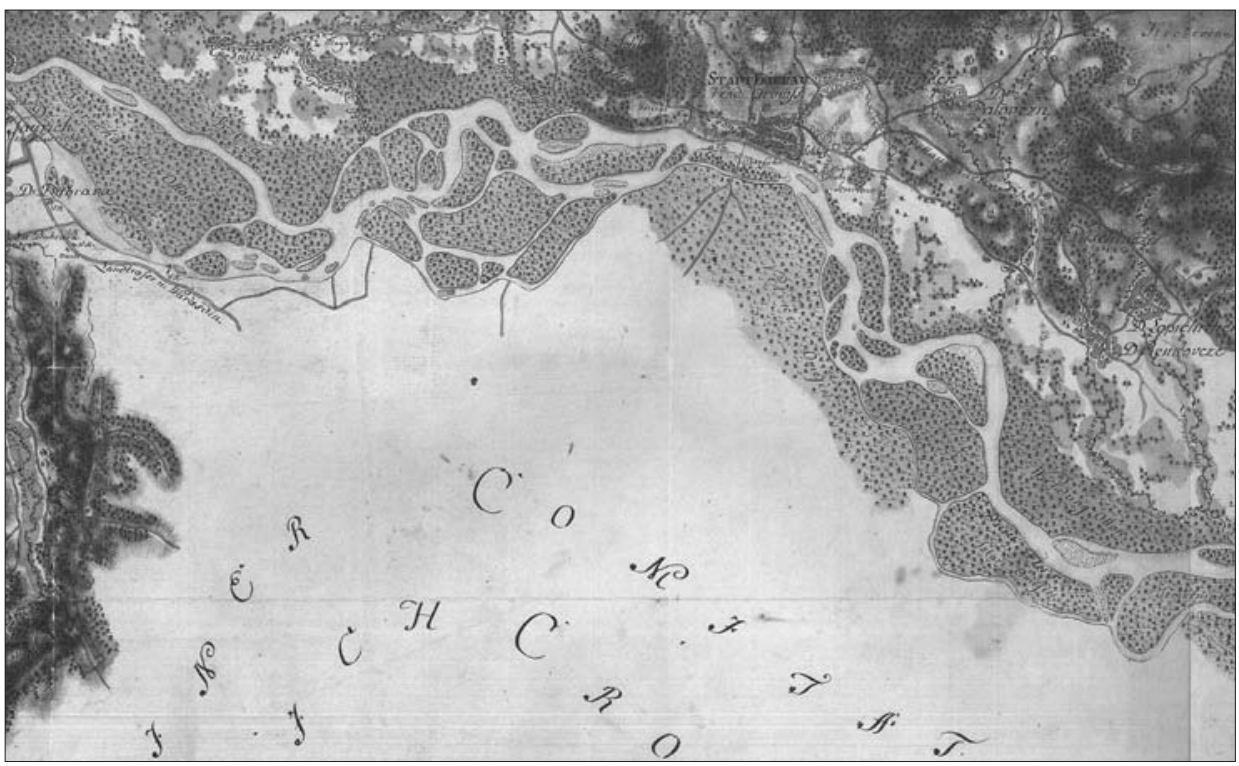

Rajšp, Vinko et al. (ur.). Slovenija na vojaškem zemljevidu 1763-1787. Zv. 6. Sekcija 197. Ljubljana, 2000

\section{Hrvaška stran južno od Ormoža}

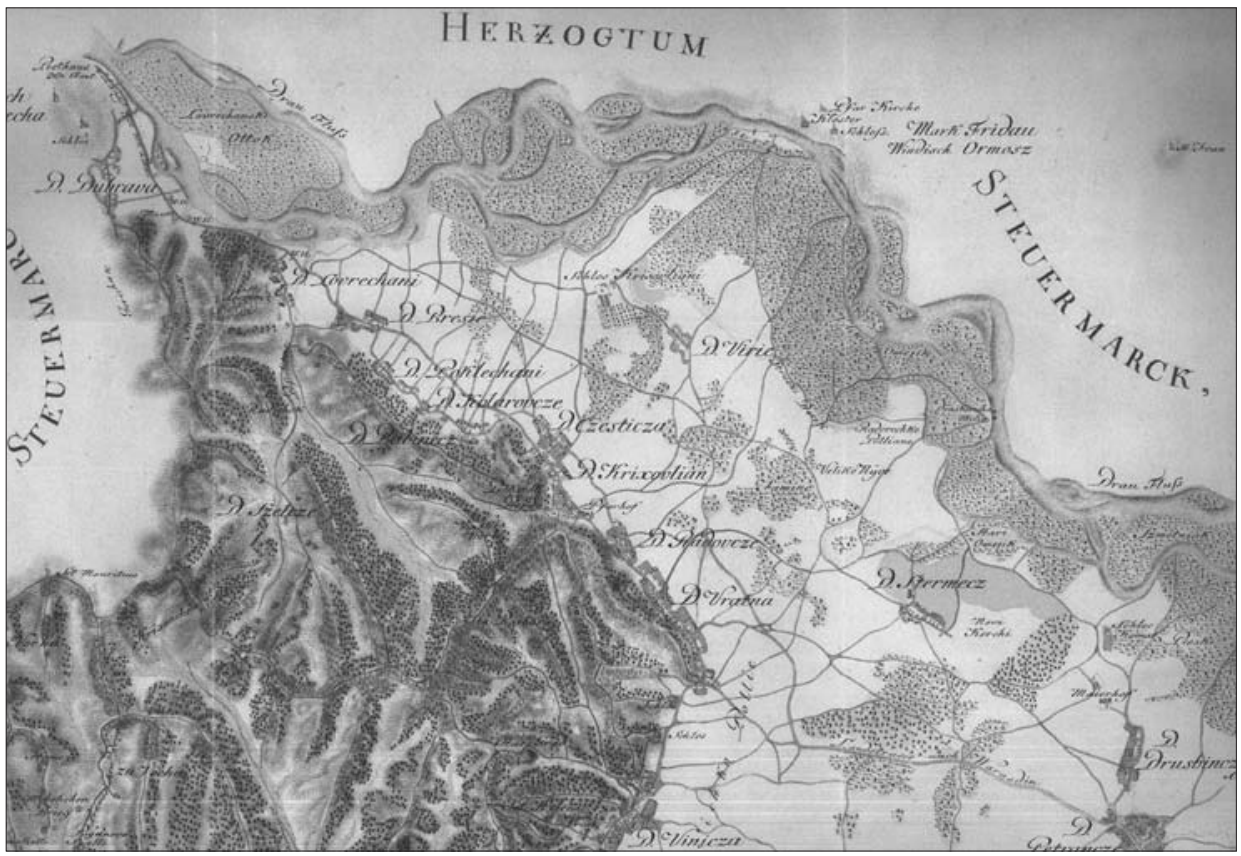

Valentić, Mirko et al. (ur.). Hrvatska na tajnim zemljovidima 18. i 19. stoljeća. Varaždinska županija. Sekcija 3. Zagreb, 2005 
podpisanimi protokoli in pooblastili) intenzivno pregledala teren, izprašala relevanthe priče in dobljene rezultate posredovala $\mathrm{v}$ presojo oblastem. ${ }^{17}$

Toda zadeva je očitno "zorela" kar nekaj časa. Medtem je dunajski dvor bral dopis, kjer je (najbrž gubernijski) pisec navajal, da se bodo podložniki, ki naj bi se že leta trudili urediti razmere, očitno primorani za uskladitev davčnih bremen obrniti neposredno na cesarico. $V$ poročilu je najvišje dvorne kroge spraševal, ali je potrebna še kakšna vizitacija reke in kako je z ozemlji, ki so v celoti prešla na hrvaško stran (saj lastnina podložnikov ne sme biti odvisna od spremenjenega toka reke). Zato je gubernij zahteval poročilo dvora glede imenovanja nove komisije, prav tako pa tudi ekspertizo prizadetih. ${ }^{18} \mathrm{Na}$ podlagi tega je leta 1779 sporne predele obiskala Navigacijska direkcija (delovala je med leti 1772-1781 pod vodstvom Gabrijela Gruberja, sicer tudi člana navigacijske komisije, ki je od leta 1774 delovala v Gradcu), detektirala stanje in podala oceno škode, ki jo je povzročila voda, v prilogi (september 1779) pa podala mogoče rešitve, načrte in mnenje (izdelal jih je »Gruberjev« inženir Ignaz Kunsti), ${ }^{19}$ po katerem bi stroški vodne zapore (z njo bi preusmerili tok vode) znašali okrog 30.000 goldinarjev. V poročilu iz januarja 1780 so stanovi navajali, da so podložniki sami prevzeli stroške tega ogleda, davek pa še zmeraj plačujejo po starem. Zato naj bi komisija na novo določila davčna bremena (in glede davka zadržala oškodovane prebivalce na isti strani reke kot poprej). Toda Kunstijeva zamisel ni prišla v poštev, saj je bila domnevno predraga, poleg tega pa je moral biti pred tem opravljen še popoln ogled spornih odsekov, ki jih je bilo še precej. ${ }^{20}$

Ne glede na podano so bili prizadeti ormoški podložniki še zmeraj brez pravne zaščite. Gubernij je sicer menil, da morajo svoje bivše parcele dobiti nazaj ali pa da se jim (na podlagi poročila iz novembra 1777) odpiše del davka. V ta namen so ponovno apelirali za novo mešano komisijo, ki naj bi razrešila zapleteni položaj (stanje stare struge je bilo (skupaj s stroški in pravnimi možnostmi) delno že detektirano z reambulacijo (ki naj bi trajala nekaj dni) na stroške ormoškega gospostva. Ko so oktobra 1780 stanovi na graški gubernij naslovili pismo, v katerem so (v skladu z dekretom iz septembra 1780) zahtevali povračilo stroškov, ki so jih založili za mejno komisijo, se je zadeva počasi začela odvijati naprej. Hrvaška stran je glede tega privolila, da sporno ozemlje pregleda inženir, v skladu s tem pa bi se nato izdelala avtentična karta terena. Na podlagi karte naj bi se tudi na novo določila višina davka za ozemlja ob reki. Gubernij je načelno sprejel stanovsko mnenje (stroškov komisije sicer ni hotel prevzeti nase) in menil, da je dejansko treba razjasniti zadevo, določiti davek in končno izrisati novo stanje. Na koncu je bilo dogovorjeno, da bo spomladi prišel inženir,

17 AT-OeStA, AVA Inneres HK Allgemein A 27 Landesgrenzen, Steiermark-Kroatien, 15501848, II. A.3. I. Öe. - Kroatien, 044 ex Dezember 1777.

18 AT-OeStA, AVA Inneres HK Allgemein A 27 Landesgrenzen, Steiermark-Kroatien, 15501848, II. A.3. I. Öe. - Kroatien, 028 ex Jänner 1786.

19 Prim. Stanislav Južnič, "Gabrijel Gruber in navigacijski inženir Jurij Vega, «Arhivi 26, št. 1 (2003): 69-79. Južnič, „Gabrijel Gruber - 2. del,« 46.

20 AT-OeStA, AVA Inneres HK Allgemein A 27 Landesgrenzen, Steiermark-Kroatien, 1550 1848, II. A.3. I. Öe. - Kroatien, 016 ex Juni 1781. 
ki bo skupaj s predstavniki ormoškega in čakovskega gospostva analiziral stanje (in opazke zabeležil, saj naj bi mape bile osnova za nadaljnje delo), stroške pa naj bi si obe gospostvi razdelili. ${ }^{21}$

Toda smeli načrti so ponovno naleteli na precej ovir. Maja 1781 je varaždinski komitat izjavil, da ne bo prevzel nobenih stroškov za komisijo, pač pa naj to izpelje ormoško gospostvo (lastnik gospostva Leopold Königsacker nad tem seveda ni bil najbolj "navdušen", kljub temu pa ga je k temu "prisilila" resolucija iz junija 1781). Številni že opravljeni ogledi niso obrodili sadov, kot je bilo načrtovano. Zadeva se je na koncu spet zavlekla za nekaj let, dokler ni mejna komisija sredi leta 1785 (zaradi pritožb štajerskih podložnikov v zvezi z mejnim sporom oziroma posestvi, ki jim jih je odnesla Drava) ponovno preučila stanja ob reki in predložila novih načrtov. Ogled je namreč pokazal, da je bila stara struga za slabo miljo prestavljena »v širino" in miljo in pol »v dolžino« (na štajersko škodo). Stroške za opravljeno delo je mariborski okrožni urad "naložil« krajem med Veliko Nedeljo in Središčem. ${ }^{22}$ Vasi, ki so utrpele najhujše izgube, Hardek, Pušenci, Loperšice, Obrež, Grabe in Frankovci, so se sprva upirale plačilu stroškov, konec leta 1785 pa so se (v več dopisih) vendarle strinjale (zastopal jih je središki pisar Johann Kasimir Lassacher Weyersberg), da bodo poravnale stroške komisije, seveda $\mathrm{v}$ upanju, da bo njeno delo obrodilo sadove. $^{23}$

V skladu s tem (in na podlagi več poročil in resolucij) je gubernij sklenil, da bo dokončno uredil mejne spore med Ormožem in Hrvaško. Mariborski okrožni urad je leta 1786 ukazal sporni teren ponovno izmeriti. Na ogrski strani je pooblastilo za izvedbo dobil varaždinski komitat (budimski namestnik je nedvoumno zapisal, da obstaja spor zaradi nove dravske struge, kar je razvidno iz katastra, in da ga je treba razrešiti), ki pa je zadevo (namesto v paru s štajersko stranjo) hotel izvesti kar sam. Zato je dvorna resolucija iz avgusta 1786 določila nove delegacije ormoškega gospostva, mariborskega urada, varaždinskega komitata in hrvaških gospostev, da bi pregledali zadevo in sprejeli smernice za nadaljnje delo. Po poročilu mariborskega urada se je ugotovilo, da je štajerska stran dejansko na izgubi, njeno nekdanjo posest pa je "okupirala" hrvaška stran (seveda je bilo stališče hrvaške strani ravno nasprotno). ${ }^{24}$ Zaradi vsega tega se je konflikt zgolj stopnjeval, oškodovanci (zastopal jih je šolski mojster Franc Jožef) pa so ponovno zahtevali mešano mejno

21 AT-OeStA, AVA Inneres HK Allgemein A 27 Landesgrenzen, Steiermark-Kroatien, 15501848, II. A.3. I. Öe. - Kroatien, 20 am November 1780; 016 ex Juni 1781.

22 Območje prim. v Andrej Hozjan, »Reka Drava in njeni signifikantni kraji na jožefinski vojaški izmeri za ozemlje republike Slovenije $=$ Die Drau und seine bedeutende Siedlungen auf der josephinischen Landesaufnahme für das Gebiet der Republik Slowenien, "v: Ekonomska i ekohistorija. Časopis za gospodarsku povijest i povijest okoliša $=$ Economic- and ecohistory. Scientific research journal for economic and environmental history 3, št. 3 (2007): 202-04.

23 AT-OeStA, AVA Inneres HK Allgemein A 27 Landesgrenzen, Steiermark-Kroatien, 15501848, II. A.3. I. Öe. - Kroatien, 028 ex Jänner 1786.

24 AT-OeStA, AVA Inneres HK Allgemein A 27 Landesgrenzen, Steiermark-Kroatien, 1550 1848, II. A.3. I. Öe. - Kroatien, 122 ex August 1786; 46 ex April 1787. 


\section{Hrvaško ozemlje južno od Središca ob Dravi}

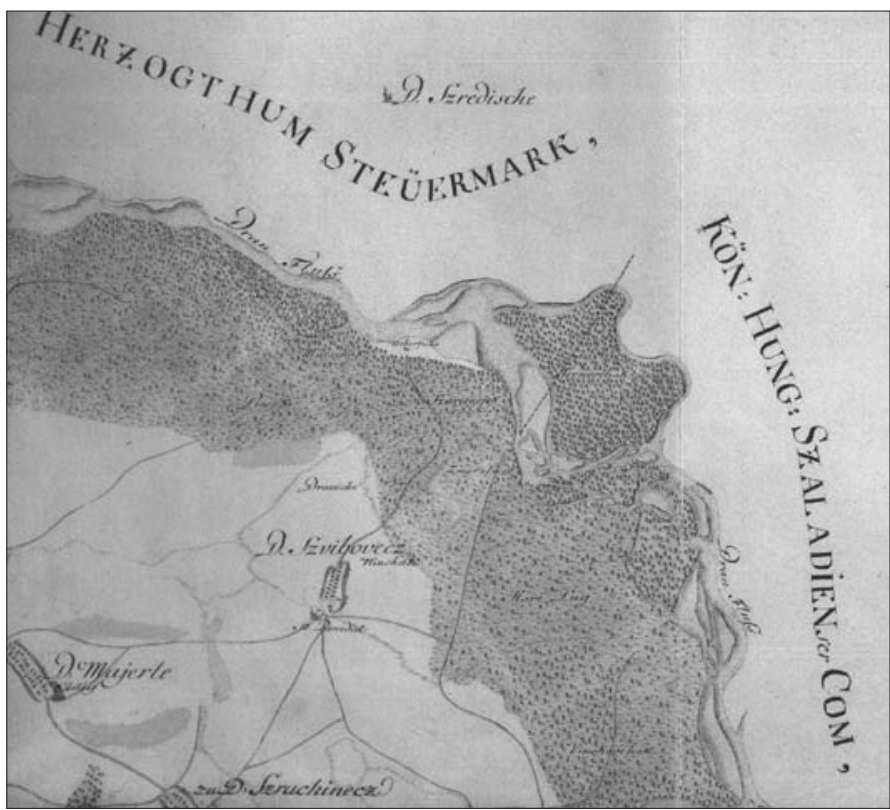

Valentić, Mirko et al. (ur.). Hrvatska na tajnim zemljovidima 18. i 19. stoljeća. Varaždinska županija. Sekcija 4. Zagreb, 2005

\section{Središče ob Dravi}

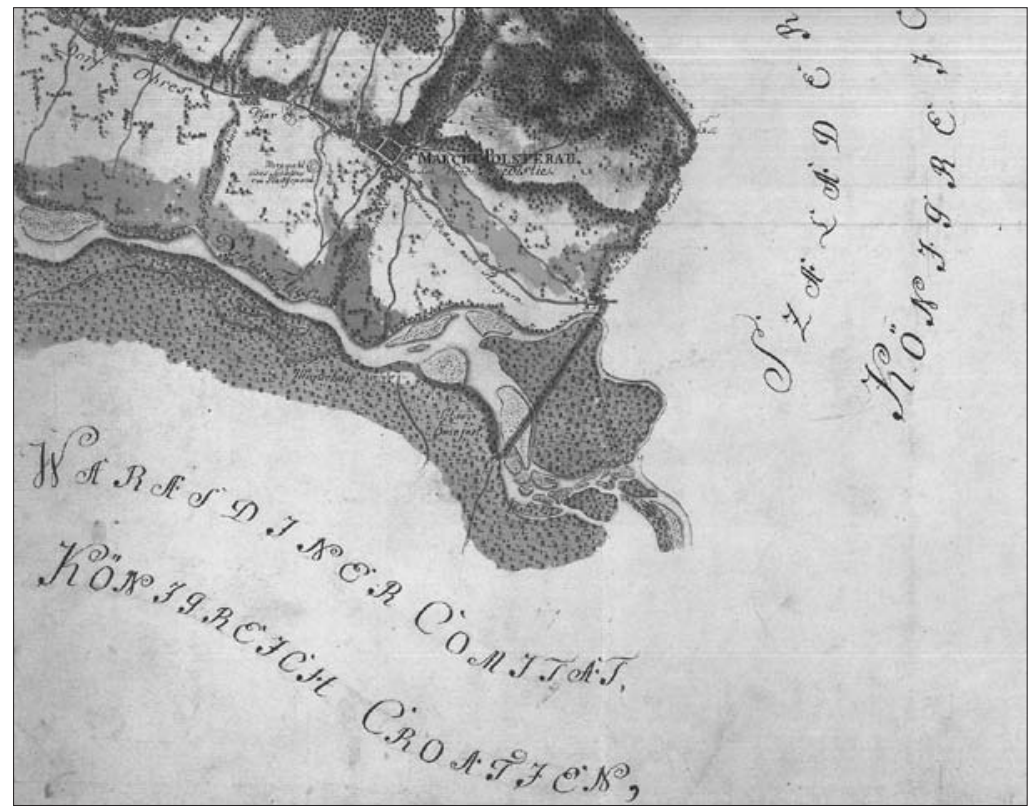

Rajšp, Vinko et al. (ur.). Slovenija na vojaškem zemljevidu 1763-1787. Zv. 6. Sekcija 198. Ljubljana, 2000 
komisijo, ki je konec leta opravila terensko delo (stroške so morali ponovno plačati podložniki ob meji). ${ }^{25}$

Kakorkoli, ogledi mešanih komisij so bolj ali manj prinašali določene rešitve, toda na koncu se je zmeraj nekje zataknilo. Zato je dvorna pisarna avgusta 1787 poslala zahtevo za dokumentacijo (oziroma korespondenco) prejšnje upraviteljice ormoškega gospostva Polixene Welsersheimb z mariborskim uradom in notranjeavstrijskim gubernijem, da bi ponovno preučila zahteve, ki so se kopičile že vse od šestdesetih let naprej. Hrvaškemu banu Ferencu Balassi je bilo tako naročeno, da poišče navedene dokumente $\mathrm{v}$ arhivu. Toda po njegovih navedbah je bilo gradivo izgubljeno (našel se je zgolj dvorni reskript, ki je potrjeval začetke hrvaško-štajerskih mejnih sporov že $\mathrm{v}$ tridesetih letih). Z iskanjem aktov so sicer nadaljevali in jih iskali tudi na varaždinskem komitatu, kjer so $\mathrm{v}$ uradnih protokolih komitata sicer našli nekaj fragmentarnih dokumentov mejne komisije, ostalega gradiva pa ne, zato so sklepali, da so najbrž zgoreli v požaru leta $1776 .{ }^{26}$

Vsi ti poskusi, da bi se stanje na rečni meji med Štajersko in Hrvaško pri Ormožu normaliziralo oziroma da bi se sporna območja, ki so bila predmet spotike že več desetletij, končno pravno uredila (z ustreznim plačilom davka in odškodnine), so bili konec 18. stoletja vse prej kot uspešni. Tudi v nadaljevanju so se spori med »sosedi« še zmeraj pojavljali, toda $\mathrm{v}$ devetdesetih letih je vendarle prišlo do prvih oprijemljivih rezultatov. Tako je mejni komisiji leta 1795 uspelo razdeliti gozd, ki sta si ga lastili štajerski gospostvi Velika Nedelja in Muretinci na eni strani ter Varaždin na drugi strani, prav tako pa leta 1797 tudi dravski otok Brode, ki je bil jedro spora med Središčem in Varaždinom. ${ }^{27}$ Komisija se je z mejo (tudi rečno) ukvarjala več let in poskušala rešiti nastali problem, pri tem pa bila večinoma neuspešna. ${ }^{28}$

Zaradi pogostih mejnih sporov in neurejenih razmer je bilo leta 1828 (po izdelavi franciscejskega katastra za Štajersko v letih 1819-1825) ${ }^{29}$ določeno, da se meja s Hrvaško končno pregleda in uredi. Štajerski stanovi so za predsednika mejne komisije imenovali grofa Antona Attemsa, na čelu hrvaške komisije pa je bil knez Phi-

25 AT-OeStA, AVA Inneres HK Allgemein A 27 Landesgrenzen, Steiermark-Kroatien, 15501848, II. A.3. I. Öe. - Kroatien, 028 ex Jänner 1786; 004 ex Martio 1787.

26 AT-OeStA, AVA Inneres HK Allgemein A 27 Landesgrenzen, Steiermark-Kroatien, 15501848, II. A.3. I. Öe. - Kroatien, 34 ex April 1788.

27 Mejne spore Središčanov z njihovimi hrvaškimi sosedi je prikazal že Fran Kovačič, a ne v smislu urejanja meddeželne meje (oziroma meje med posestniki), pač pa večdesetletnega "nagajanja" glede služnostnih pravic, paše ipd. (od šestdesetih let 18. stoletja do tridesetih let 19. stoletja). Žal je Kovačič pri svojem opisovanju zelo poljuden oziroma precej skop pri sklicevanju na svoje vire. Prim. Kovačič, Trg Središče, 485-504.

28 StLA, Statthalt, 78-5063/1885, K 2930, Landesgrenze Steieremark-Croatien, št. 14334, 12.11. 1829; št. 6735, 30. 9. 1831.

29 Več o tem gl. Zbirka Franciscejski kataster za Štajersko. Dosje zbirke (Maribor: Pokrajinski arhiv, 2009). SI AS 177, Franciscejski kataster za Štajersko, 1823-1869. 
lipp Bathyan. Stanovi so zadolžili zemljiške gosposke in okrajne oblasti, ki so bile kakorkoli povezane s spornimi zemljišči, da pripravijo potrebno dokazno gradivo $\mathrm{v}$ izvirniku ali overovljene prepise, na podlagi katerih bi lahko odločali o poteku meje. Komisija, ki je opravljala delo na meji mariborskega okrožja in varaždinskega komitata, se je sestala 31. avgusta $1829 .{ }^{30}$ Med svojim delom je naletela na težave z mejo predvsem na njenih rečnih odsekih. Ker se meja med Varaždinom in Središčem ni ujemala s potekom meje $\mathrm{v}$ starejših kartah, je bila v novem osnutku nekoliko spremenjena oziroma prilagojena trenutnim razmeram. ${ }^{31}$ Sedmega oktobra je komisija končala delo in sprejela zaključne sklepe. Pri spornih ozemljih do Ormoža (ki so bila dotlej v skupni rabi) je Štajerska obdržala večji del dravskega otoka (Brode) med Varaždinom in Središčem z gozdom občine Grabe, medtem ko je naslednji otok (Sekel), ki je v starejših listinah pripadal Hrvaški, ostal v hrvaški lasti. Ostala sporna ozemlja do Ormoža so pripadla Štajerski, tako da je bila Štajerska po določitvi meje na tem delu v ugodnejšem položaju kot hrvaška stran. ${ }^{32}$

Meja med Štajersko (celjsko in mariborsko okrožje) in Hrvaško (zagrebški in varaždinski komitat) je bila tako usklajena in izrisana jeseni 1829, mariborsko in celjsko okrožno glavarstvo pa sta 12 . novembra oziroma 6. decembra 1829 poslali na graški gubernij dopis, v katerem sta ga seznanjali z doseženim stanjem na štajersko-hrvaški meji. ${ }^{33} \mathrm{Na}$ posameznih predelih je meja sicer (ponovno) razdelila posest, tako da je bil del te v eni deželi in del v drugi, to pa je na štajersko-hrvaški meji tudi v nadaljevanju sprožalo številne mejne spore med posestniki. ${ }^{34}$

\section{Viri in literatura}

Arhivski viri:

- OeStA, Österreichisches Staatsarchiv:

o AT-OeStA/AVA Inneres HK Allgemein A 27 Landesgrenzen, Steiermark-Kroatien, 1550 1848, II. A.3. I. Öe. - Kroatien; Stmk - Kroatien.

- SI AS, Arhiv Republike Slovenije:

- SI AS 177, Franciscejski kataster za Štajersko, 1823-1869.

- StLA, Steiermärkisches Landesarchiv:

o Statthalt 78-5063/1885, K 2930, Landesgrenze Steieremark-Croatien.

Literatura:

- Curk, Jože. »Oris Ormoža in Središča v fasijskem popisu iz leta 1754." V: Ormož skozi stoletja III, ur. Peter P. Klasinc, 73-79. Ormož: Skupščina občine, 1988.

30 StLA, Statthalt, 78-5063/1885, K 2930, Landesgrenze Steieremark-Croatien, št. 14334, 12. 11. 1829.

31 StLA, Statthalt, 78-5063/1885, K 2930, Landesgrenze Steieremark-Croatien, Übereinkommen, št. 14209, 16. 9. 1829.

32 StLA, Statthalt, 78-5063/1885, K 2930, Landesgrenze Steieremark-Croatien, št. 14334, 12. 11. 1829.

33 Prim. StLA, Statthalt, 78-5063/1885, K 2930, Landesgrenze Steieremark-Croatien, št. 14334, 12. 11. 1829; Übereinkommen, št. 12757, 6. 12. 1829.

34 Več gl. v Ivanka Zajc Cizelj, Okrožni urad Celje 1798-1850 (Celje: Zgodovinski arhiv Celje, 1998), 12-19. 
- Heindl, Waltraud in Edith Sauer. „Grenzen und Grenzüberschreitung. Die Bedeutung der Grenze für die staatliche und soziale Entwicklung des Habsburgerreiches von der Mitte des 18. bis zur Mitte des 19. Jahrhunderts."V: Ästhetik und Ideologie, 277-90. Wien: Bundesministerium für Wissenschaft und Verkehr, 1997.

- Hozjan, Andrej. „Reka Drava in njeni signifikantni kraji na jožefinski vojaški izmeri za ozemlje republike Slovenije $=$ Die Drau und seine bedeutende Siedlungen auf der josephinischen Landesaufnahme für das Gebiet der Republik Slowenien. "V: Ekonomska i ekohistorija. Časopis za gospodarsku povijest $i$ povijest okoliša $=$ Economic-and ecohistory. Scientific research journal for economic and environmental history 3, št. 3 (2007): 190-205.

- Mirko Valentić, Alexander Buczynski, Ivana Horbec, Milan Kruhek in Mica Orban Kljaić, ur. Hrvatska na tajnim zemljovidima 18. i 19. stoljeća. Varaždinska županija. Zagreb: Hrvatski institut za povijest, 2005.

- Južnič, Stanislav. „Gabrijel Gruber in navigacijski inženir Jurij Vega. «Arhivi 26, št. 1 (2003): 69-80.

- Južnič, Stanislav. „Gabrijel Gruber in navigacijski inženir Jurij Vega - 2. del.« Arhivi 29, št. 1 (2006): 35-63.

- Korunić, Petar. Jugoslavenska ideologija u Hrvatskoj i slovenskoj politici. Hrvatsko-slovenski politički odnosi 1848-1870. Zagreb: Globus: Centar za povijesne znanosti sveučilišta u Zagrebu, Odjel za hrvatsku povijest, 1986.

- Kovačič, Fran. Trg Središče. Krajepis in zgodovina. Maribor: Zgodovinsko društvo za Sl. Št., 1910.

- Pickl, Othmar. "Mur und Drau als Verkehrswege nach dem Südosten."V: Razvoj prometnih zvez v panonskem prostoru do 1918. leta, ur. Vanek Šiftar in Janko Kuster, 225-40. Maribor: Univerza v Mariboru, 1977.

- Podgoršek, Nataša. Slovensko-hrvaška vzajemnost. Zgodovina slovensko-hrvaških političnih odnosov v drugi polovici 19. stoletja: 1848-1903. Maribor: Zgodovinsko društvo dr. Franca Kovačiča, 2009.

- Rahten, Andrej. Zavezništva in delitve. Razvoj slovensko-hrvaških političnih odnosov v habsburški monarbiji 1848-1918. Ljubljana: Nova revija, 2005.

- Vinko Rajšp, Marija Grabnar in Vladimir Kološa, ur. Slovenija na vojaškem zemljevidu 1763-1787. Zv. 6. Ljubljana: ZRC SAZU, 2000.

- Darko Darovec, Petar Strčić, Breda Biščak, Hrvoje Ratkajec, Karmen Medica, Simon Kerma, Milan Bufon in Jože Pirjevec, ur. Slovensko-hrvaško sosedstvo. Hrvatsko-slovensko susjedstvo. Koper: Univerza na Primorskem, ZRS, Univerzitetna založba Annales in Zgodovinsko društvo za južno Primorsko, 2011.

- Valenčič, Vlado. »Prebivalstvo Ljubljane pred dvesto leti.« Kronika 2, št. 3 (1954): 191-200.

- Zajc Cizelj, Ivanka. Okrožni urad Celje 1798-1850. Celje: Zgodovinski arhiv Celje, 1998.

- Zajc, Marko. "Sotla, majhna voda."Zgodovina za vse 19, št. 1-2 (2012): 101-13.

- Zajc, Marko. Kje se slovensko neha in hrvaško začne. Slovensko-hrvaška meja v 19. in na začetku 20. stoletja. Ljubljana: Modrijan, 2006.

- Zbirka Franciscejski kataster za Štajersko. Dosje zbirke. Maribor: Pokrajinski arhiv, 2009.

Filip Čuček

ON THE ISSUE OF THE STYRIAN-CROATIAN BORDER ON THE RIVER DRAVA AT THE END OF THE $18^{\text {TH }}$ CENTURY

S U M M A RY

The provincial border river Drava played an important role in the part of the Styrian-Croatian border which is the subject of this discussion. Frequent changes of its flow (at certain parts of its water courses), resulting from the excess amounts of water (especially in the middle of the $18^{\text {th }}$ century), caused numerous conflicts and tensions until the end of the 1920s, when the Styrian-Croatian border was finally agreed upon.

The river bed changes used to represent a pressing problem for the people who lived by the river Drava. The complaints of the serfs from the border areas were considered for the first time by the special 
border commission in 1754 in the context of the proposed tax reform, but the revision was initiated only in connection with Hungary and not with Croatia. The complaints were recompiled in 1773 by Count Brandis, a legal representative of the Ormož Seigniory, but the problems remained unsolved. The authorities in Vienna thus only started to deal with this issue more seriously in the middle of the 1870s. In February 1775 a decree was issued in order to finally settle the question of tax liability (and the compensation for damages) in the areas, affected by the changed Drava river bad. An imperial appeal issued in October 1775 somewhat improved the legal status of the serfs, but the practical enforcement of the provisions turned out to be problematic.

As the situation at the border still remained unsolved, the tax burdens of the affected peasants had to be re-determined and the compensation for the lost estates had to be established as well. Consequently the Gubernium proposed the elaboration of a topographic map of both sides of the border to settle the taxation matters. A special commission reviewed the disputed territory on the Styrian side. It concluded that the remaining estates should be protected and that water construction should be initiated. Regardless of the ambitious plans, the "opposite" side, which actually profited the most from the changed river bed, refused to agree with the plans.

Because the matter came to a "standstill", the Navigation Directorate visited the disputed areas in 1779 in order to determine the situation and assess the damages caused by the water. In the annex the Directorate also stated possible solutions, plans and the opinion of engineer Ignaz Kunsti stating that the construction of a barrage would amount to approximately 30.000 goldinars. But Kunsti's idea was not taken into account because it was supposedly too expensive, and the affected serfs in Ormož would remain without legal protection. At the end of 1780 the Croatian side nevertheless finally agreed to the inspection of the disputed territory by an engineer in order to draw up an authentic map of the territory.

However, the ambitious plans yet again stumbled upon numerous obstacles. In May 1781 the Varaždin County stated that it would not assume any costs for the Commission, and that the Ormož Seigniory should carry out this project. Once again the matter dragged on for a few years until the border commission re-examined the situation by the river in the middle of 1785 and came up with new plans. The examination revealed that the old river bed had moved for almost a mile "in width" and a mile and half "in length" (to the detriment of the Styrian side). In 1786 the District Office of Maribor issued an order to perform a new survey of the disputed territory together with the Varaždin County, but the Hungarian side wanted to carry it out by itself (and not in cooperation with the Styrian side). Therefore in August 1786 a new delegation of the Ormož Seginory, the District Office of Maribor, the Varaždin County and the Croatian seignories was appointed to review the matter and adopt the guidelines for future work. The District Office of Maribor established that the Styrian side was in fact the one who had suffered losses and that its previous estates had been "occupied" by the Croatian side (who claimed the opposite). Thus the conflict intensified (and work came to a standstill). The aggrieved parties finally demanded a new border commission.

The examinations performed by the mixed commissions managed to bring about certain solutions, but ultimately they always somehow proved to be ineffective. A part of the StyrianCroatian border was already determined at the end of the $18^{\text {th }}$ century, while in the beginning of the $19^{\text {th }}$ century the mixed commissions attempted to solve the border issues more or less unsuccessfully. Due to frequent border disputes and disorder, in 1828 a decision was reached that the border with Croatia should be reviewed and regulated. The border was agreed upon and drawn in the autumn of 1829. However, in certain areas it divided the estates, and the changing riverbeds as well as inconsistent land relations caused numerous border disputes between landowners. 